\title{
Territorial Factors, Geo-Politics and Great Powers Relations: The Case of Indonesia-Malaysia and South East Asian Region in the 1961-1971
}

\author{
Mohd. Noor Mat Yazid \\ Programme of International Relations, Faculty of Humanities, Arts and Heritage, Universiti Malaysia \\ Sabah, Kota Kinabalu, Malaysia
}

\begin{abstract}
This article focuses on the discussion of the territorial factors, geo-politics, great powers relations and related issues in the Indonesia-Malaysia political relations during the period 1961-1971. The territorial factor and geo-politics were among the vital factors in the Indonesia-Malaysia political relations and great power relations in the South East Asia Region. It had a close relationship with the economic factor, idiosyncratic and ideological conflict. Both sides of the hegemonic (the U.S.) and counter-hegemonic power (the Soviet Union) were involved in the Indonesia-Malaysia conflict. The geographical position of Indonesia's and Malaysia's territory was vital for both sides of the great powers (and also for China Communists). Hence, the discussion and analysis of the territorial factor had a close relationship with the geo-politics, international ideological factors, economics and idiosyncratic factors. The changes in ideological development, economic situation, changes in leadership and changes in systemic power configuration affected the territorial factor. The changes in the above mentioned factors during the period before and after 1965 in Indonesia had a great impact upon the territorial issue and the political relations of Indonesia-Malaysia and great powers relations in the South East Asian Region.
\end{abstract}

Keywords: territorial factors, geo-politics, great power relations, Indonesia, Malaysia, The United States, Soviet Union, South East Asia.

\section{INTRODUCTION}

This article focuses on the discussion of the territorial factors and related issues in the IndonesiaMalaysia political relations during the period 1961-1971. Economic and security-political interests are closely related with the territorial factor. Greater Indonesia, under Muhammad Yamin Plan, claimed the broad territorial border, including most parts of the area under British protection in Borneo (Sabah and Sarawak) as well as the Federation of Malaya. The Indonesian Plan for the formation of 'Greater Indonesia' could threaten the interests and position of the American hegemonic power in the Southeast Asian region. ${ }^{1} \quad$ Indonesian external relations that were closer to the communists and gained support from them, influenced the Americans to become involved in the conflict. The territorial claim by Indonesia under the 'Greater Indonesia' plan could threaten the American and Western powers' position in the region. This article tries to determine the importance of the territorial factor and the relationship with the three levels of analysis (regional, domestic and systemic) in influencing and shaping the Indonesia-Malaysia political relations during the period 1961-1971.

\section{History, GeOgraphical Location, Territorial FaCtOR AND GeO-Politics}

The geographical location of Indonesia and Malaysia is very strategic. Both states are situated in the centre of the Southeast Asian region and on the vital trade routes from East Asia and Europe. During the colonial period and before World War II, the region was dominated by two European powers; the Dutch in the south part and the British in the north part. Before the colonial era, there were no apparent boundaries between Malaysia and Indonesia. The provinces of the Southern part of Thailand and Southern Philippines also had similar characteristics of religion and culture and were considered

1 Mohd. Noor, Mat Yazid, 2000, 'Ideological and Territorial Factors in Malaysia-Indonesia Confrontation 1963-1966,' Asian Profile, vol. 28 , no.4, August 2000, pp. 303-308. 
as a part of the 'Malay' world. Both provinces shared similar characteristics of culture and religion with Indonesia and Malaysia. ${ }^{2}$ The ancient great Kingdom in the Malay world such as Majapahit, Sriwijaya, Sultanate of Malacca, Sultanate of Sulu and Magindanao, Sultanate of Brunei and Acheh Kingdom, covered the areas of both countries, i.e. the current region of Indonesia and Malaysia.

The Anglo-Dutch Treaty of 1824, signed between Great Britain and the Netherlands on 17 March 1824, was vital in the Malay world division. ${ }^{3}$ Although the treaty's main objective was to solve the problem of political relations of post Napoleon war between Britain and the Netherlands (especially the problem of the new port of Singapore) it was essential for the basic boundary of both modern Malay nations, Indonesia and Malaysia. The Treaty in 1824 divided the Malay world into two powers of influence; the Dutch in Indonesia and the British in Malaysia.

During the Japanese occupation of 1941-1945, the Japanese united both sides of the Straits of Malacca, Sumatra, Singapore and Malaya into one political administration. There was only one centre of administration between Malaya, Singapore and Sumatra. The relations between the people in Malaya and Sumatra were close. Apart from trade, there were family and social relationships among them. They shared the same culture, language and same religion. The geography and historical background between the three parts of the political unit, i.e. Federation of Malaya, Singapore and Sumatra influenced the close political relationship, especially during the first two decades after the war. The close socio-cultural relations and geographical factors between the Federation of Malaya, Singapore and Sumatra continued after the Japanese occupation and even after a few decades after independence.

The political development after the Japanese surrendered in August 1945 had separated the three political units that were created by the Japanese. Sumatra became independent when Indonesia proclaimed independence on $17^{\text {th }}$ of August 1945, Malaya and Singapore became a British colony as before the Second World War with a different type of administration.

The geographical position of Sumatra and Malaya influenced the political relations between Indonesia and Malaysia. In terms of locations, culture, language and religion, Sumatra was closer to Malaya than Java. The collapse of the combined Hatta-Sukarno administration in 1956 had influenced the political development in Sumatra. ${ }^{4}$ The break-down in the co-operation between Sukarno-Hatta in 1956 had an effect upon the PRRI rebellion in 1958. Had the Sukarno government not destroyed the the PRRI government 1958, the possibility of Sumatra joining the Federation of Malaya as a political unit was great. ${ }^{5}$

The territorial and geographical location of Sumatra and Malaya played a significant role in the political development in Southeast Asia during the early decades of the Cold War. The geo-political development in the 1950's and the 1960's saw that Sumatra's geographical location was important for defence and also for Indonesian national security.

\section{Greater Indonesian Plan and the Territorial Boundary of Four Asian POWERS}

Greater Indonesia or "Indonesia Raya" (in Malay-Indonesian language) was the long-term Indonesian territorial boundary drafted by Professor Muhammad Yamin (deputy Prime Minister of Indonesia). The 'Indonesia Raya Proposal' included the whole area of the Netherlands East Indies, (including

\footnotetext{
2. Southern Part of Thailand and the Philippines are similar with Malaysia and Indonesia. The majority population is Muslim and generally follows Malay-Muslim culture.

3 . The Anglo-Dutch Treaty of 1824 was vital in studying the politics, economic and social developments in the Malay world. From that event the Malay world officially was divided into two, i.e Indonesia (under Dutch) and Malaysia (under British).

${ }^{4}$. Mohd Hatta was a strong political leader from Sumatra who became vice-President when Indonesia declared independence in 1945.

5 .Nik Anuar Nik Mahmud, 2000, Konfrontasi Indonesia-Malaysia (Indonesian-Malaysia Confrontation), Bangi; Penerbit Universiti Kebangsaan, p. 12 \& p. 80. Sumatra's geographical location and its cultural relationship with Malaya become one of the political issues in Malaysia-Indonesia political relations in the 1950s and 1960s.
} 
West Irian), Malaya, Singapore, Brunei, Southern part of Thailand and the Southern part of the Philippines.

Indonesia planned to control the major part of Southeast Asia and become one of the four great Asian powers. ${ }^{6}$ After the fall of the European powers in Southeast Asia, the region should have returned to the traditional borders as before the coming of Europe to the Malay region. From the Sukarno Indonesian perspective, there were only four great powers in Asia, namely China, Japan, India and Indonesia. ${ }^{7}$ The title of Indonesia as one of the four great Asian powers was recognised by China. The whole part of Southeast Asia was recognised by China's communists as Indonesian territory.

The physical boundary was one of the important indicators for Indonesia to achieve her ambition as one of the great Asian powers. With the boundary under the 'Muhammad Yamin Plan' Indonesia would be able to dominate the major part of the Southeast Asian region and then become the single major power in the Southeast Asian region, with China and Japan as the major power in the East Asian region and India as the major power in South Asia.

All of the four Asian major powers in Sukarno's Indonesian perspective should have had their own sphere and be made responsible to protect themselves from outside interference. In this context, the formation of the Federation of Malaysia in 1963 was an intrusion to the Indonesian sphere. There was Indonesian responsibility to protect their region from the outsider (British).

\section{THE TERRITORIAL FACTOR AND THE 1958 PRRI REBELLION IN SUMATRA}

The PRRI (Pemerintahan Revolusioner Republik Indonesia) rebellion in Sumatra and PARMESTA in Celebes in 1958 were the two important internal rebellions in Indonesia. The main objectives of both rebellions were to create an independent state from the central government in Jakarta free from Sukarno's political control.

The disagreement with the central government in Jakarta after the broken PNI-Masjumi-Nahdatul Ulama alliance in 1956, the split between Hatta and Sukarno and several economic and political disagreements with Sukarno, contributed to the outbreak of the rebellions. The disagreement concerned the unequal cabinet minister's participation in Sukarno's Cabinet and top administrative positions in Sukarno's administration. The Sukarno-communist co-operation and their influence in President Sukarno's regime also influenced the outbreak of the rebellion. The people who were from Java's ethnic origin controlled most of the cabinet ministers and top positions in the Indonesian central government in Jakarta. There were very small numbers of the people from outside Java (nonJava origin) who held top positions in the cabinet and Jakarta's central government in the late 1950s. ${ }^{8}$

The rebellion's leaders in Celebes and Sumatra were supported by the Masjumi political party (Majlis Sjura Muslimin Indonesia) and Western powers, especially the United States and Great Britain. Masjumi was a Muslim political party that had strong support from the rural population from outside Java, ${ }^{9}$ especially from Sumatra, Celebes and other outer islands.

The United States and Great Britain gave financial and weapons support to the PRRI and Parmesta rebellion forces. Singapore, Penang (and other small ports in Malayan Federation) and Labuan in Borneo were used as the bases for supporting and providing for the rebellion in Sumatra and Celebes.

This territorial issue (i.e. the geography location) and the role played by Singapore, Penang and Labuan during the rebellion of 1958 as military bases became a significant territorial issue for the 1960's Indonesian security under Sukarno's regime. In the eyes of Sukarno, those territories were essential for Indonesian security. With the military and strategic development in the 1958 rebellion,

\footnotetext{
${ }^{6}$. China's Communists recognised that the whole part of Southeast Asian archipelagos should be under Indonesian political control.

${ }^{7}$. In the Southeast Asian region the whole region should be under Indonesian control. Malaysia was not recognised by Sukarno because in Sukarno's view Malaysia was a 'British puppet' and the formation of Federation of Malaysia in 1963 was a British strategy in maintaining their power in Southeast Asian region. The position and Indonesia's future role in Southeast Asia had been recognised by Communist China.

8 . Jamal, Erryhan, "Asal-Usul Pecahnya Pemberontaakan Pemerintah Revolusioner Republik Indonesia (PRRI): Politik Indonesia 1954-1958" (The Origin of the PRRI: Indonesian Politics 1954-1958), unpublished Masters thesis, Department of Political Science, Universiti Kebangsaan Malaysia, 1986.

${ }^{9}$.West Java is excluded. In Indonesia, Java more specifically refers to East and central Java. In this case West Java gave their support to Masjumi.
} 
Sukarno thought that both sides of the Straits of Malacca (Sumatra and Federation of Malaya coastal areas) were vital for future Indonesian security. In Borneo Island, the British territory of Sabah (British North Borneo), Sarawak and Brunei were also significant for Indonesia's future security. External foes could use the territories to attack Indonesia's territory from the Malaysian part of Borneo Island. The territorial factor was considered important in Indonesia-Malaysia's relationship of the 1960's based on the security development in the late 1950s. As long as British military bases were in Singapore and other parts of Malaysia, the territorial borders with Indonesia (especially Sabah-Sarawak, Labuan, West Coast of Malaya and Singapore) were seen as important for Indonesian security.

\section{Sumatra-Java and Sumatra-Malaya Culture Relations}

The characteristics of the Sumatra-Java relations and Sumatra-Malaya relations have some differences. In terms of culture, language, religion factor, historical background and geographical location, Sumatra was closer to Malaya than Java. Culturally there were many differences between Java and Sumatra. Java had her own culture that differed from Sumatra. The language, culture and style of living between the two Indonesian main islands were different. In the aspect of language and culture, Sumatra was closer and had many similarities with Malaya. This was because of the location, historical background and political relations before 1949 between Sumatra and Malaya.

Before the colonial period, both Sumatra and Malaya were under the Malacca Sultanate. Malacca Sultanate was a strong kingdom that controlled both parts of the Malacca Strait for more one hundred years before the Portuguese came. After the Portuguese invaded Malacca in 1511, the relations between Malaya and Sumatra were still close under a few Malay local kingdoms. The Malay Kingdom after the fall of Malacca, i.e. Acheh Sultanate and Sultanate of Johore covered both sides of Malaya and Sumatra. The Portuguese only had control over the port of Malacca, but not the whole part of the former Malacca Empire. The Southern part of Malaya and major parts of Sumatra were still controlled by the hereditary Sultan of Malacca one hundred years after the Portuguese invaded Malacca in 1511.

The political boundary between Malaya and Sumatra was only made apparent by the Anglo-Dutch Treaty on $17^{\text {th }}$ March 1824. Sumatra and other islands southward of Singapore fell under the Dutch administration, and Malaya (and north part of Singapore) fell under the British sphere of administration. The relations among the population in Sumatra and Malaya still continues. Acheh was free from the Dutch control until the 1870's. The Malay states in Malaya (Perak, Selangor, Negeri Sembilan) were also free from British control until 1874, after The Pangkor Treaty was signed in January 1874. Johore and other Malay states in Malaya were still free from British control until the outbreak of the First World War in 1914. The British signed the treaty with Thailand in 1909 (Bangkok Treaty) to control the four northern Malay states, i.e. Perlis, Kedah, Kelantan and Terengganu from Thai. The treaty of 1914 with the Sultan of Johore was signed between the British and Johor to secure British protection over the state of Johore. Both treaties were forced by the political development of pre-first world war in Europe, i.e. the rivalry between the British hegemony and Germany as a new rising world power.

During the Japanese occupation of 1941-1945 Sumatra and Malaya were united into one administration and under one political unit. The historical background and the close geographical location influenced the relations between both states in the early decades after they gained independence from European colonial masters.

\section{Two Cultures-One Country and One Culture-Two Countries}

The relations between Malaya and Sumatra in the early decade after independence could be said to be 'one culture within the two countries' based upon the similarities between Sumatra and Malaya. On the other side, the relations between Sumatra and Java could be said to be 'two cultures within one country' because of their differences in culture, language and style of living. The differences and the territorial factor gave a vital impact to the outbreak of the PRRI rebellion in 1958 in Sumatra. The similarities and closer relationship between Malaya and Sumatra brought dissatisfaction among the leaders in Jakarta. 


\section{Territorial, GEO-PolitiCS AND INDONESIAN SECURITY}

The territory factor is important for the geo-politics and military-security consideration. In Sukarno's view, Indonesia needed the territory on both sides of the Straits of Malacca and the west part of Borneo (British North Borneo or Sabah, Sarawak and Brunei) for her political stability and militarysecurity consideration. The geo-political position in the early 1960's was not secure for Indonesia. The Indonesian enemy would have used the territory (Malaya and British parts of Borneo) to encircle the Indonesian part, especially Kalimantan (Indonesian part of Borneo island) and Sumatra. The experience in the late 1950's was evidence for Indonesia to learn a lesson with such a geo-political structure. Indonesia argued that the formation of Malaysia in 1963 was a strategy to strengthen British power and her position in the Southeast Asian region and to encircle Indonesia in the future. Sukarno was not happy with the military and defence agreement between Malaysia and Great Britain. ${ }^{10}$ As a result of the rebellion of 1958 and the relations with Western support to PRRI and Parmesta, Sukarno put high consideration upon the position of adjacent borders of Sumatra and Kalimantan. Both parts of adjacent parts of British territory were vital for Indonesian security.

\section{Indonesian, North Kalimantan Federation State and Sheikh Azahari of Brunei}

Indonesia gave full support to Sheikh Azahari (Brunei's People Party leader) to form The North Kalimantan Federation State, (NKFS). This federation planned to merge North British Borneo (Sabah), Sarawak and Brunei under one unit of political administration with the capital in Brunei. This federation, argued by Azahari, was a pure independent state from any colonial powers. It was a rebirth of the Brunei Kingdom because the entire region in West Borneo was under the Sultanate of Brunei before the coming of colonial powers into this region (the Spaniards, the Dutch and the British). The federation gained support from left-wing political parties in the Borneo British territories. The pro-British political leaders had a different view. Its British responsibility was to protect British Borneo territories from becoming a pro-communist territorial sphere.

Indonesia gave support to the North Kalimantan Federation because Azahari was pro-Indonesia and anti-West. With the formation of North Kalimantan Federation States, President Sukarno would create another ally in Southeast Asia that would strengthen the Indonesian position in Southeast Asian international politics.

The territory of North Kalimantan Federation States was considered important for Sukarno in two aspects; firstly, for security (as mentioned above) and secondly, for the economic factor of oil reserves, especially in Brunei and the north part of Sarawak. Brunei is one of the richest states in the world (the position of Brunei in Southeast Asia is like Kuwait in the Middle East). Brunei is a small state with less than 300,000 population and very rich with gas and petroleum. If Brunei had been under Azahari who was pro-Indonesia, Sukarno could have used the close relations with Azahari to assist Indonesia with its economic problems. Alternatively, if Brunei had joined the Malaysian Federation (as Sultan of Brunei agreed earlier) it would have benefited to Malaysia and Great Britain. In the Brunei factor, geo-politics and geo-economics were both important for Indonesia.

\section{SABAh, the PhIlippines and the Greater Indonesian Plan}

Sabah was an important issue in the relations between Malaysia, Indonesia and the Philippines. Sabah was a British colony and the British government agreed to relinquish it for the formation of the Malaysian Federation. The Philippines argued that Sabah was under the Philippines' territory and should be returned to the Philippines' government. ${ }^{11}$ It was alleged that the North Borneo Company had a lease from the Sultan of Sulu (the hereditary leader was the Philippines government) in 1878. Therefore the Chartered Company should return Sabah to its hereditary leaders when the period expired.

The Philippines, government claimed the territory because Sabah was the Philippines' right (according to the Philippines' argument) and the Sabah issue would have become more difficult when

10. Anglo-Malayan Defence Agreement (AMDA) was signed between Federation of Malaya and Great Britain in September 1957. Great Britain also had military bases in Singapore.

11. For the detailed discussion of the Philippines claims over Sabah, see Nik Anuar Nik Mahmud, 2000,Konfrontasi Indonesia-Malaysia (Indonesia-Malaysia Confrontation), chapter 4. 
the formation of Malaysia succeeded or Sabah joined the North Kalimantan Federation States, under Azahari's plan that was supported by Indonesia.

The Sabah issue created bad diplomatic relations between Malaysia and the Philippines. This issue destroyed the new birth of regional association, i.e. the Association of Southeast Asian States (ASA) that was created in 1961 by the three states, Thailand, Malaya and the Philippines. However, the Sabah issue and the Philippines' claim rested well with the West's capitalist spirit and America and Great Britain interfered in the issue. To the American hegemony, the Sabah issue that was raised by the Philippines was not important for his economic and political interest in Southeast Asia compared to the conflict between Malaysia and Indonesia. The influence of a hegemonic power and political relations between America and the Philippines paved the way to the solution of the PhilippinesMalaysia conflict over Sabah. ${ }^{12}$ Political conflicts between both pro-American hegemonic powers are seen as being easier to solve. The different conflict solution between the Philippines-Malaysia and Indonesia-Malaysia was due to the different policy of the Philippines pro-hegemony and Indonesian anti-hegemony.

\section{Territorial Factors, Security AND the Great PoWers' Rivalry}

This part discusses the importance of the territorial factor in the communist-capitalist struggle, i.e. China and the United States. China's communists supported Indonesia in the international ideological and territorial struggle and on the other side the United States and Great Britain were fighting Indonesia in protecting Malaysian territory.

The territorial factor became one of the important factors in the great powers' relations. The creation of a communist sphere of influence after World War II became important for American security and territorial planning in the East and Southeast Asia in the 1950's and 1960's. The spread of communist territorial activity in Mainland China in 1945 and in Indochina in 1954 was significant in American territorial policy in East Southeast Asia. The communist struggle in Indochina in the 1960's gave a signal for the U.S. about the strength of Communism in Asia in the 1960's. The position of the Indonesian Communist Party in early 1960s in Indonesian government made the territorial factor even more vital in American policy in Southeast Asian archipelagos.

The broad Indonesian territory/the biggest country in the region was important for American territorial planning in Southeast Asia. America realised this development as early as the 1950's. America gave support to the regional rebellion in Indonesia. The most significant was the PRRI and Parmesta rebellion in Sumatra and Celebes in 1958. America had been involved in the PRRI in Sumatra in 1958 with great support for the creation of independent states from Sukarno's Indonesia. For America, Indonesia, (especially Sumatra and Celebes) was very important for her economic natural resources. America hoped to control both sides of the Straits of Malacca (one of the vital sea routes from East and Europe). America failed to form a government that was pro-West in Sumatra in 1958.

The rebellion of 1958 was important for Indonesia and Malaysia for their future territorial planning. Both sides of the Straits of Malacca were significant for Indonesia and Malaya. American support towards the PRRI and Parmesta were clear to Sukarno. The roles played by the British ports in the Federation of Malaya and British Borneo during the PRRI rebellion made it important for Sukarno's planning of the defence-territorial factor. The Malayan ports such as Penang, Singapore, Labuan etc. had been used to aid the rebellion in Indonesia.

The territorial factor was important in two aspects. Firstly, for the security and military reason and secondly for economic development and natural resources. The different ideologies and rivalries between the democratic-capitalist sphere and the socialist-communist sphere made the territorial factor one of the vital factors.

12. See Mohd. Noor Mat Yazid, 2004, 'The Philippines-Malaysia Political Relations, 1961-1965: Domestic and Systemic Elements,' The Philippines International Conference, International Institute for Asian Studies, University of Leiden, The Netherlands, 16-19 June 2004. 


\section{The Territorial Factor and Political Development After 1967: The United STATES, INDOCHINA CRISIS AND THE ROLE OF REgIONALISM}

Political development in Indonesia and in the whole of the Southeast Asia after 1967 affected the territorial factor and its solution in Southeast Asia. The common threat from the North ${ }^{13}$ made the territorial issue different from the years before 1967. The emergence of Indonesia as a strong democratic-capitalist country in the Southeast Asian region after $1967^{14}$ gave great impact to the state of foreign relations in the region. The formation of ASEAN increased the degree of co-operation among the capitalist members state. ASEAN capitalist countries had closer relations due to their democratic-capitalist ideology and were facing the same enemy from the communist North. All of the political developments after 1967 gave great impact to the territorial issue in the region. The political relations and territorial conflict between Indonesia and Malaysia was affected by the development after 1967.

\section{Indonesia Domestic Policy and Territorial Stability After 1965}

During the half-decade after the September event of 1965, which affected the territorial stability in the Malaysia and Indonesian region, Indonesia's territorial expansion that began during Sukarno's regime had been halted. The changes in Indonesia's domestic condition explained and were responsible for the development in the region. The 'New Order' Indonesia during the period before 1971 was concentrated upon the domestic power and political consolidation. New order was needed to build a strong political foundation at the domestic level. The territorial expansion, especially towards the Western sphere (towards Malaysia region) ceased in 1966. Indonesia's new order tried to avoid any conflict with Western powers. ${ }^{15}$ Suharto's Indonesia needed economic support from the West for their political and economic survival. The more important agenda for a new regime was to make a stronger position in economic terms. The only way to achieve a strong economic position was through economic support from Western countries.

The Indonesian general election in 1971 was important for the new regime's government in Indonesia. After the Golkar Party obtained a strong position in the 1971 Indonesian general election, the new regime started to form her effective foreign policy. The territorial sea and related issues about territory began after 1971. The territorial conflict with Malaysia did not become a major factor in the political relations between both countries during the period 1967 to 1971. ASEAN anti-communist spirit and regional capitalist co-operation played a significant role during this period.

\section{Cultural Factor and Territorial Settlement}

The role of Sumatran perception and Malayan people also contributed to the territorial settlement between Indonesia and Malaysia. Leaders from Sumatra played a more significant role in Indonesian foreign relations after 1965. The new perception of the Indonesian leaders towards Malaysia gave vital impact to the political relations between both states. The conflict which related to the territorial issue was easily solved with the new perception towards Malaysia. The culture and family factor contributed to the territorial settlement after 1967. The role played by Tun Adam Malik of Indonesia, Mohd. Ghazali Shafie and Tun Abdul Razak of Malaysia was significant in settling the territorial dispute between both countries. The culture factor and family relationship was significant in these cases. Tun Adam Malik, Foreign minister of Indonesia was half Malaysian. ${ }^{16}$ Mohd Ghazali Shafie and Tun Razak had close family ties with Indonesia. The family and cultural factor contributed to the harmonious relations and smooth territorial negotiation at the state level.

13. The threat from Mainland China towards democratic-capitalist countries in Southeast Asian region.

14. After 1967 the position of Suharto became stronger. President Sukarno was overthrown from power, communist leaders and members were destroyed and most of the political power was under the army and President Suharto.

15. Especially from the United States and Great Britain. Confrontation with Malaysia must be ceased promptly because the Federation of Malaysia was directly supported by Great Britain.

16. He was born and brought up in Perak, Malaysia until eight years old when he migrated to Sumatra, Indonesia. Malayan Peninsular and Sumatra Indonesia was just separated by narrow straits (Straits of Malacca). Both parts have similar language, religion and culture. In some aspect the Malaya-Sumatra relations were closer than Sumatra-Java relations. Java has their own language and slightly different culture. 


\section{Territorial Stability, Domestic Policy, Regionalism and Systemic Situation}

This part will discuss the relationship between the territorial problem, Indonesia's domestic politics, regionalism and the systemic situation. How did the domestic policy and systemic situation influence the territorial claim and the crisis between the two countries?

The formation of a regional association in Southeast Asia was important in settling the territorial problem in the Malaysia-Indonesia political relations. The territorial factor had connections with the security matter. The formation of ASEAN in 1967 was officially for co-operation in economic, cultural and technological terms. ASEAN was also regarded as part of the Western regional grouping with a motive of military and regional security. All of the ASEAN members ${ }^{17}$ (except Indonesia) were members of the military Alliance with one or more Western countries. ${ }^{18}$ The security and military factors influenced Indonesian territorial policy towards Malaysia. As a pro-West member of the regional organisation, Indonesia considered that the territorial issue was not a vital issue in the relations with both countries.

In the period after 1965, the territorial issue was not a major issue in Indonesia-Malaysia's relations because of the stable domestic situation in Indonesia. The 'New Order' government had another political agenda, especially in consolidating the position of army politics and destroying the internal communist threat in Indonesia. The Indonesian new regime needed Malaysian support, both economically and politically. Hence the territorial issue became less important.

The Indonesian territorial issue was different during the period before 1965. Sukarno considered the territorial issue was important for Indonesia's security, national expansion and for economic advantages. The ideological factor and external support from China and Soviet Union influenced Indonesia's territorial policy.

\section{Conclusion}

This article discusses the significance of territorial factors in explaining Indonesia-Malaysia's political relations during the period 1961-1971. The territorial factor was one of the vital factors in IndonesiaMalaysia's political relations. It had a close relationship with the economic and idiosyncratic factors and also with the ideological conflict. The geographical position of Indonesia's and Malaysia's territory was vital for both sides (and also for China) of the great powers. Hence the discussion and analysis of the territorial factor having a close relationship with the ideological, economic and idiosyncratic factors. The changes in ideological development, the economic situation, changes in leadership and changes in the systemic power configuration affected the territorial factor. The changes in the above mentioned factors during the period before and after 1965 had a great impact upon the territorial issue and Indonesia-Malaysia's political relations.

\section{REFERENCES}

[1] Ahmad, Abdullah, (1985), Tengku Abdul Rahman and Malaysia's Foreign Policy 1963-1970, Kuala Lumpur: Berita Publishing.

[2] Allison, R., and William, P., (1990), Superpowers Competition and Crisis Prevention in The Third World, Cambridge: Cambridge University Press.

[3] Anwar, Dewi Fortuna, (1997), Indonesia in ASEAN: Foreign Policy and Regionalism, Singapore: Institute of Southeast Asian Studies.

[4] Bangau, W., (1981), 'Surging Towards Regional Co-operation: The case of ASEAN,' (Unpublished Master Dissertation, The University of Birmingham, England).

[5] Boyce, P. J., (1977), Foreign Affairs for New States: Some Questions of Credentials, St. Lucia, Queensland: University of Queensland Press.

${ }^{17}$. Thailand and the Philippines were the SEATO members, while Malaysia and Singapore had special military relations and a defence agreement with Great Britain (under Anglo-Malayan Defence Agreement in September 1957).

18 . Roesnadi, O. Sutomo, 1973, 'ASEAN and The Great Powers,' The Indonesian Quarterly, vol. 1, no. 4, July 1973, pp.19-20. 
[6] Brecher, Michael, (1963), 'International Relations and Asian Studies: The Subordinate State System of Southern Asia,' World Politics, vol. 15 (2), pp.213-235.

[7] Bucklin, W. T., (1972), 'Regional Economic Co-operation in South East Asia; 1954-1969,' (Unpublished Ph.D thesis, Michigan State University).

[8] Buszynski, L., (1981), 'SEATO: Why It Survived until 1977 and Why It was Abolished,' Journal of Southeast Asian Studies, vol. xii, no. 2, (September), pp. 287-296.

[9] Butwell, R., (1964), 'Malaysia and Its Impact on The International Relations of Southeast Asia,' Asian Survey, vol. iv, no. 7, pp. 940-946.

[10] Crouch, Harold, (1972), 'Military Politics under Indonesia's New Order,' Pacific Affairs, vol. 42, no. 2, (Summer 1972)), pp. 206-219.

[11] Curtis, Robert, (1964), 'Malaysia and Indonesia,' New Left Review, vol.28, (November-December), pp. 532.

[12] Dalton, J. B., (1967), 'The Development of Malayan External Policy 1957-1963,' (Unpublished Ph.D thesis, University of Oxford, Oxford).

[13] Derkach, Nadia, (1965), 'Soviet Policy towards West Irian and Malaysian issues,' Asian Survey, vol. 5, no.11 (November 1965), pp.566-571.

[14] Feith, Herbert, (1964), 'President Sukarno, The Army and The Communists: The Triangle Changes Shape,' Asian Survey, vol. iv, no. 8, August 1964, pp. 969-980.

[15] Gordon, Bernard, K. (1964), 'Problems of Regional Cooperation in Southeast Asia,' World Politics, vol. xvi, no. 2, (January 1964), pp. 222-253.

[16] Gordon, Bernard, K., (1966), The Dimensions of Conflict in Southeast Asia. New Jersey: Prentice-Hall.

[17] Gordon, Bernard, K., (1966), 'Regionalism and Instability in Southeast Asia,' Orbis,, vol. $x$ (no. 2 Summer), pp. 438-457.

[18] Hazra, Niranjan Kumar, (1965), 'Malaya’s Foreign Relations 1957-1963,' (M.A. thesis, Department of History, University of Singapore, 1965)

[19] Heidhues, M. F. S., (1966), 'Peking and the Overseas Chinese: The Malaysian Dispute,' Asian Survey, vol. vi, (no. 5), pp. 276-287.

[20] Hindley, Donald, (1962), 'President Sukarno and The Communists: The Politics of Domestication,' The American Political Science Review, vol. LVI, no. 4, (December), pp. 915-926.

[21] Hindley, Donald, (1963), 'Foreign Aid to Indonesia and Its Political Implication,' Pacific Affairs, vol. xxxvi, no.2, ( Summer), pp. 107-119.

[22] Hindley, Donald, (1964), 'Indonesia's Confrontation with Malaysia: A Search for Motives,' Asian Survey, vol. iv, no. 6, pp. 904-913.

[23] Hindley, Donald, (1968), 'Indonesian Politics 1965-1967; The September Movement and the Fall of Sukarno,' The World Today, vol. 24(August 1968), pp. 345-356.

[24] Horn, R. C. (1971), 'Soviet-Indonesian Relations since 1965,' Survey, (Winter 1971), pp. 216-232.

[25] Horn, R. C. (1973/74), 'Indonesia's Response to Changing Big Power Alignments.' Pacific Affairs, vol. 46, no. 4, (Winter 1973/74), pp. 515-533.

[26] Horn, R. C. (1975), 'Soviet Influence in Southeast Asia: Opportunities and Obstacles,' Asian Survey, vol. xv, no.8. (August 1975), pp. 656-671.

[27] Jamal, Erryhan, (1986), 'Asal-Usul Pecahnya Pemberontakan Pemerintah Revolusioner Republik Indonesia (PRRI): Politik Indonesia 1954-1958,' (The Origin of the PRRI: Indonesian Politics 1954-1958), (unpublished Masters thesis, Department of Political Science, Universiti Kebangsaan Malaysia, 1986).

[28] Jefferson, J. K. (1972), 'The Indonesian Confrontation with Malaysia, 1963-1966,' (Unpublished Master thesis, The University of Birmingham).

[29] Jones, M. (2000), 'Creating Malaysia: Singapore Security, the Borneo Territories, and the Contours of British Policy, 1961-63,' The Journal of Imperial and Commonwealth History, vol. 28, no.2, (May), pp. 85-109.

[30] Kahin, G. M. (1964), 'Malaysia and Indonesia,' Pacific Affairs, vol. xxxvii (Fall), pp. 253-270.

[31] Kahin, G. M., Pauker, G. J., \& Pye, L. W. (1955), 'Comparative Politics of Non-Western Countries,' American Political Science Review, vol. XLIX, pp. 1022-1041.

[32] Kroef, J. M. v. d. (1960), 'Indonesia in The Cold War,' Current History, vol. xxxviii (February), pp. 8894.

[33] Kroef, J. M. v. d. (1963), 'Indonesia, Malaya and The North Borneo Crisis,' Asian Survey, vol. iii (no. 4), pp.173-181. 
[34] Kroef, J. M. v. d. (1966), 'Communism in Sarawak Today,' Asian Survey, vol. vi, no. 10, pp. 568-579.

[35] Kroef, J. M. v. d. (1969), 'New Political Patterns in Indonesia,' The World Today, vol. 25(May 1961), pp. 219-230.

[36] Legge, J. D., (1963), 'Indonesia after West Irian,' Australian Outlook, vol. xvii (no. 1 April), pp. 5-20.

[37] Leifer, Michael, (1964), 'Anglo-American differences over Malaysia,' The World Today, vol. 20(April 1964), pp. 156-167.

[38] Leifer, Michael, (1965), 'Indonesia and Malaysia: the Diplomacy of Confrontation,' The World Today, vol. 21(June 1965), pp. 250-260.

[39] Leifer, Michael, (1966), 'Indonesia and Malaysia: The Changing Face of Confrontation,' World Today, vol. 22, no. 9, (September 1966), pp. 395-405.

[40] Leifer, Michael, (1970), 'Indonesia's Future Role,' The World Today, vol. 26, (December 1970), pp. 512519.

[41] Leifer, Michael, (1980), Conflict and Regional Order in South East Asia. London: International Institute of strategic Studies.

[42] Leifer, Michael, (1983), Indonesia's Foreign Policy. London: George Allen \& Unwin.

[43] Levi, W. (1968), The Challenge of World Politics in South and Southeast Asia Englewood Cliffs, N.J.: Prentice-Hall, Inc.

[44] Lim Kian Tick, (1998), 'Regionalism in Malaysia's Foreign Policy, 1957-1990: State Building, Regional Organisations and the Continuing Malay Dilemma,' (Ph.D. thesis, Linacre College, University of Oxford, 1998).

[45] Mackie, J. A. C. (1961), 'Indonesian Politics Under Guided Democracy,' The Australian Outlook, vol. 15, no. 2, pp. 260-279.

[46] Mackie, J. A. C. (1964), 'Indonesia: a background to 'Confrontation',' The World Today, vol. 20, (April 1964), pp. 139-147.

[47] McIntyre, A. (1973), 'The Greater Indonesia: Idea of Nationalism in Malaya and Indonesia,' Modern Asian Studies, vol. 7, no. 1, pp. 75-83.

[48] Mohd Noor Mat Yazid, (2000), 'Asia Tenggara dan Sistem Bipolar,' (Southeast Asia and Bipolarity System), Pemikir, no. 20, April-June 2000, pp. 1-20.

[49] Mohd.Noor Mat Yazid, (2000), 'Ideological and Territorial Factors in the Indonesia-Malaysia Confrontation 1963-1966,' Asian Profile, vol. 28, no. 4, August 2000, pp. 303-306.

[50] Mohd Noor Mat Yazid, (2004), 'The Philippines-Malaysia Political Relations 1961-1965: Domestic and Systemic Elements,' (International Conferences of the Philippines Studies, University of Leiden, International Institute for Asian Studies, 16-19 June 2004)

[51] Muhammad Muda, (1991), 'Malaysia's Foreign Policy and the Commonwealth'. Round Table, 320, (October), pp. 455-466.

[52] Nadesan, Alexander, 1979, 'Sino-Indonesian Relations (1950-1967) and Its Future?', Indian Journal Journal of Politics, April-August 1979.

[53] Nik Anuar Nik Mahmud, (2000), Konfrontasi Indonesia-Malaysia (Indonesian-Malaysian Confrontation), Bangi: Penerbit Universiti Kebangsaan Malaysia.

[54] Ott, Marvin,C., (1971), 'The Sources and Content of Malaysian Foreign Policy towards Indonesia and the Philippines 1957-1965,' (Ph.D. dissertation, The John Hopkins University, 1971).

[55] Paget, R., K., (1967/68), 'The Military in Indonesian Politics'. Pacific Affairs, Vol. XL, (no. 3 \& 4 Fall and Winter 1967/68), pp. 294-314.

[56] Pauker, G., J. (1963), 'Indonesia: Internal Development or External Expansion?' Asian Survey, vol. iii, (no. 2), pp. 69-75.

[57] Pauker, G. J. (1962), 'The Soviet Challenge in Indonesia', Foreign Affairs, no.4, (July 1962), pp. 612-626.

[58] Pauker, G. J. (1967), 'Indonesia: The Year of Transition.' Asian Survey, vol. vii, no. 2, (February), pp.138150.

[59] Pollard, V.K. (1970), 'ASA and ASEAN, 1961-1967: Southeast Asian Regionalism', Asian Survey, vol. 10, no. 3 (March 1970).

[60] Pollard, V. K. (1971), 'South East Asian Regionalism', Journal of Contemporary Asia, vol. 1, no. 4, pp. 45-54.

[61] Polomka, P. (1972), 'The Indonesian Army and Foreign Policy: A Reappraisal', Asia Quarterly, vol. 4,no. 4, pp. 363-382. 
[62] Quiko, Eduard, (1970), 'The Role of Foreign Minister Subandrio in Indonesian Politics: Analysis of Selected Indonesian Foreign Policies, 1957-1965,' (Ph.D dissertation, Department of Government, Southern Illinois University, July 1970).

[63] Range, W. (1966), ‘Sukarnoism: An Interpretation'. Orbis, vol. x, no. 2, (Summer), pp. 488-506.

[64] Rudner, M. (1970), 'The Malaysian General Election of 1969: A Political Analysis'. Modern Asian Studies, vol. 4, no. 1, pp. 1-21.

[65] Saravanamuttu, Johan, (1983), The Dilemma of Independence: Two Decades of Malaysia's Foreign Policy, 1957-1977, Penang: Universiti Sains Malaysia.

[66] Schmitt, H.O., (1963), 'Post-colonial Politics: a suggested interpretation of the Indonesian experience, 1950-1958', Australian Journal of Politics and History, vol. 9, no. 2, pp. 176-183.

[67] Scott, P. D. (1985), 'The United States and Overthrow of Sukarno, 1965-1967,' Pacific Affairs, 58, (no. 2 Summer), pp. 239-264.

[68] Silcock, T. H. (1963), 'The Development of a Malayan Foreign Policy,' Australian Outlook, vol. 17, (no. 1 April), pp. 42-53.

[69] Singh, B. (1994), Indonesia-Soviet Relations, Jogjakarta: Gadjahmada University Press.

[70] Smith, T. E. (1962), 'Proposals for Malaysia,' The World Today, vol. 18, no. 5, (May 1962), pp. $192-200$.

[71] Smith, T. E. (1963), 'The Brunei Revolt: Background and Consequences,' The World Today, vol. xix, no.4, (April), pp. 135-138.

[72] Smith, T. E. (1963), 'Progress towards Malaysia and the Brunei Revolt,' The World Today, vol. 19, (January 1963), pp. 6-8.

[73] Stockwell, A. J. (1998), 'Malaysia: The Making of a Neo-Colony?', The Journal of Imperial and Commonwealth History, vol. 26, no. 2, ( May), 138-156.

[74] Stubbs, R. (1990), 'Canada's Relations with Malaysia: Packing Partners in ASEAN', Pacific Affairs, vol. 63, no. 3, Fall 1990.

[75] Subritzky, J.A., (1997), 'Britain, the United States, Australia, New Zealand and the Malaysian-Indonesian Confrontation 1961-1965,' (Ph.D thesis, Christ's College, University of Cambridge, February 1997).

[76] Subritzky, J.A., (2000), 'Britain, Konfrontasi, and the End of Empire in Southeast

[77] Asia, 1961-65'. The Journal of Imperial and Commonwealth History, vol. 28, no. 3, (September), pp. 209227.

[78] Suchahyo, (1967), 'The New Order in Indonesia'. World Marxist Review, October 1967, pp. 46-48.

[79] Sukma, Rizal, (1995), 'The Evolution of Indonesia's Foreign Policy: An Indonesian View,' Asian Survey, vol. xxxv, no. 3, ( March 1995), pp. 304-315.

[80] Sullivan, J. H., (1969), 'The United States and the 'New Order” in Indonesia,' (Ph.D dissertation, School of International Service, The American University, Washington D.C. 1969).

[81] Sutter, J., O. (1966), 'Two Faces of Konfrontasi: "Crush Malaysia" and the Gestapu'. Asian Survey, vol. iv, no. 10 , pp. 523-546.

[82] Tilman, R. O. (1969), 'Malaysian Foreign Policy: The Dilemma of a Committed Neutral', in J.D.Montgomery \& A. D. Hirchman (eds.) pp. 115-159.

[83] Vincent, K. P. (1970), ‘ASA and ASEAN, 1961-1967:Southeast Asian Regionalism'. Asian Survey, vol. 10, (March), pp. 244-255.

[84] Weatherbee, D.E., 1962, 'Indonesia and Malaysia: Confrontation in Southeast Asia,' Orbis, Summer 1962, pp. 336-351.

[85] Weinstein, F. B. (1972), 'The Uses of Foreign Policy in Indonesia: An Approach to the Analysis of Foreign Policy in the Less Developed Countries,' World Politics, vol. 24, pp. 356-381.

[86] Weinstein, F. B. (1976), 'The Foreign Policy of Indonesia' in Rosenau, J.N., \& K. W. Thompson \& G. Boyd (eds.), World Politics: An Introduction (pp. 239-262). New York: The Free Press.

[87] Williams, L. E. (1962), 'Sino-Indonesian Diplomacy: A Study of Revolutionary International Politics,' The China Quarterly, vol. 11, (July-September), pp. 184-199.

[88] Woo Jung Ju, (1967), 'The Rise and Fall of the Djakarta-Peking Axis, 1949-1966,' (Ph.D. dissertation, Department of History, State College, Mississippi, January 1967)

\section{AUTHOR's BIOGRAPHY}

Mohd. Noor Yazid, is an associate professor in International Relations specialising in International Politics of the Asia Pacific Region at The Programme of International Relations, School of Social 
Territorial Factors, Geo-Politics and Great Powers Relations: The Case of Indonesia-Malaysia and South East Asian Region in the 1961-1971

Sciences, Universiti Malaysia Sabah since 1997. He obtained a first degree in Development Science from Universiti Kebangsaan Malaysia, Bangi; Masters degree in International Relations from University of Leeds, England and Ph.D in Asian Studies and International Relations from The University of Birmingham, England.

Citation: Mohd. Noor Mat Yazid. " Territorial Factors, Geo-Politics and Great Powers Relations: The Case of Indonesia-Malaysia and South East Asian Region in the 1961-1971." International Journal of Political Science (IJPS), vol 3, no. 4, 2017, pp. 15-27. doi:http://dx.doi.org/ 10.20431/2454-9452.0304002.

Copyright: (๑) 2017 Authors. This is an open-access article distributed under the terms of the Creative Commons Attribution License, which permits unrestricted use, distribution, and reproduction in any medium. provided the original author and source are credited. 